\title{
STUDI EKSPERIMENTAL PENGARUH KECEPATAN ALIRAN MASUK, SPLIT - RATIO DAN DIAMETER VORTEX FINDER TERHADAP UNJUK KERJA LIQUID- LIQUID CYLINDRICAL CYCLONE (LLCC) SEPARATOR
}

\author{
Irfan Aditya Dharma ${ }^{1 *}$, Adhika Widyaparaga ${ }^{2}$, Alim Yuandia ${ }^{3}$ \\ Jurusan Teknik Mesin, Fakultas Teknologi Industri, Universitas Islam Indonesia ${ }^{1}$ \\ Jalan Kaliurang Km.14,5, Sleman, Yogyakarta, 55501 \\ Pusat Studi Energi, Universitas Gadjah Mada2, Sekip Blok K1-A, Yogyakarta, 55281 \\ Departemen Teknik Mesin dan Industri, Fakultas Teknik, Universitas Gadjah Mada ${ }^{2,3}$ \\ Jalan Grafika No.2, Yogyakarta, 55281 \\ E-Mail :.rfan.adharma@uii.ac.id ${ }^{1}$,adhika@ugm.ac.id ${ }^{2}$,alim.yuandia@mail.ugm.ac.id
}

\begin{abstract}
The large number of ports in Indonesia generate a lot of waste oil that contaminate the ocean around the port. However, the pollution prevention is not supported by a good facility. Hydrocyclone separator can be used as an alternative to supporting conventional separataor technologies such as vessel type separator or gravitational based separator to prevent the waste oil pollution. The purpuse of this study is to determine the effect of split ratio, inlet mixture velocity, and vortex finder diameter on the performance of the liquid-liquid cylindrical cyclone (LLCC). Oil (Kerosene) and water were selected as the working fluid and a red color (dye) was given to the oil to enable visualization. Performance of LLCC determined from watercut that produced from separation process. The examined inlet mixture velocity are $0.7 \mathrm{~m} / \mathrm{s}, 0.9 \mathrm{~m} / \mathrm{s}$ and $1.1 \mathrm{~m} / \mathrm{s}$ with split-ratio $5 \%, 15 \%, 30 \%, 45 \%$, $60 \%, 75 \%$ and $90 \%$. All of them are tested with vortex finders that have diameters $18 \mathrm{~mm}, 22 \mathrm{~mm}$ and $27 \mathrm{~mm}$ with $0 \mathrm{~mm}$ depth. The oil volume fraction inlet is kept constant at $25 \%$. The result showed that LLCC was capable to separating oil-water mixture and produced watercut on underflow reaches $100 \%$. The increasing of split-ratio will increase the watercut until reached the maximum value for all diameter of vortex finder. The condition when the oil content begin to move to the underflow on certain split-ratio is called oil drag. The split-ratio that used before oil drag occurs is called Optimum Split Ratio (OSR). LLCC should operated on OSR to obtain the best performance. The OSR is shifted to the higher split-ratio for higher inlet mixture velocity. The increasing of vortex finder diameter did not change LLCC performance significantly.
\end{abstract}

Keywords : Hydrocyclone Separator, LLCC, Inlet Mixture Velocity, Split-Ratio, Vortex Finder, Watercut, Oil Volume Fraction.

\section{PENDAHULUAN}

Indonesia merupakan negara kepulauan yang dihubungakan dengan sarana penghubung yaitu pelabuhan. Dengan banyaknya jumlah pelabuhan di Indonesia, tentunya menimbulkan jumlah limbah minyak buangan kapal yang cukup banyak dan mencemari lautan di sekitar pelabuhan. Namun, sampai saat ini, penanganan limbah tersebut tidak didukung dengan fasilitas yang mumpuni (Eryanto \& Achmadi, 2012). Penanggulangan pencemaran limbah dapat dilakukan dengan cara memisahkan kandungan minyak dalam air. Metode pemisahan air dan minyak yang sering digunakan saat ini adalah metode konvensional seperti gravity-based dan veseel-type separator. Separator tersebut relatif mahal dan memakan waktu pengoperasian yang cukup lama (Liu, Xu, $\mathrm{Wu}$, \& Zheng, 2010). Penelitian ini mengembangkan metode baru yang lebih murah dan efisien untuk mendukung penggunaan separator konvensional yaitu metode cyclone separator atau lebih dikenal dengan nama hydrocyclone separator. Tipe hydrocyclone yang digunakan adalah tipe liquid-liquid cylindrical cyclone (LLCC). LLCC merupakan teknologi baru dalam pemisahan air dan minyak (Oropeza- 
Vazquez dkk., 2004). LLCC memiliki desain yang relatif lebih sederhana daripada hydrocyclone yang umum digunakan. LLCC terdiri dari pipa vertikal dengan inlet horizontal dimana campuran minyak dan air masuk secara tangensial. LLCC sendiri menggunakan prinsip aliran vortex, dimana aliran vortex merupakan salah satu jenis pola aliran dimana alirannya bergerak mengitari sumbu pusatnya. Gerakan tersebut menimbulkan gaya sentrifugal. Karena perbedaan densitas, air akan terlempar ke bagian dinding dan minyak akan terkumpul di bagian pusat. Aliran kaya minyak akan keluar melalui bagian atas (overflow), sedangkan aliran kaya air akan keluar melalui bagian bawah (underflow).

Banyak sekali studi tentang LLCC yang sudah dipublikasikan terkait performa, desain, parameter operasi, maupun kontrol dari LLCC. Dari segi desain dan performa, (Listewnik, 1984) menunjukkan pengaruh penggunaan empat inlet terhadap efisiensi separasi cylindrical hydrocyclone. (Berdnasky \& Listewnik, 1988) menganalisis efek diameter inlet terhadap efisiensi separasi dari hydrocyclone. (Liu dkk., 2012) melakukan studi eksperimental terkait efek dari parameter operasi yaitu split-ratio dan laju aliran masuk terhadap performa separasi LLCC. (Dharma dkk., 2016) mengevaluasi performa LLCC sebagai alat penghasil air bersih (water knock-out device).

Namun, studi - studi diatas dilakukan dengan menggunakan desain LLCC yang berbeda - beda. Sayangnya, tiap desain LLCC memiliki perilakunya masing masing. Hal ini tentunya mempersulit pengoperasian LLCC itu sendiri. Untuk itu, perlu diketahui hubungan antara parameter operasi (kecepatan aliran masuk, split-ratio, dan fraksi volume minyak inlet) dan parameter desain (diameter inlet, ketinggian LLCC, ukuran vortex finder, dll) terhadap unjuk kerja dari LLCC. Parameter desain tersebut akan diubah menjadi parameter non - dimensi. Penelitian ini bertujuan untuk mendapatkan database eksperimental yang nantinya akan digunakan untuk membuat sebuah Peta Operasi dari LLCC (LLCC Operation Map). Peta Operasi tersebut berisikan perilaku untuk berbagai desain LLCC dalam sebuah database terpadu.

\section{METODE PENELITIAN}

Fasilitas eksperimental LLCC ini bertempat di Laboratorium Mekanika fluida dan Perpindahan Kalor dan Massa Departemen Teknik Mesin dan Industri, Fakultas Teknik, Universitas Gadjah Mada.

Skema dari sistem aliran fluida pada LLCC terdapat pada Gambar 1. Pada skema tersebut terdapat dua buah tangki yang digunakan untuk menampung minyak dan air dengan kapasitas masing - masing $250 \mathrm{~L}$. Masing - masing tangki terhubung dengan pompa. Dua buah pompa tersebut digunakan untuk memindahkan air dan minyak agar tercampur dan masuk ke LLCC.

Air dan minyak tanah yang berada di dalam tangki dipompa menuju mixture tube. Mixture - tube tersebut berfungsi untuk mencampur air dan minyak sebelum masuk ke LLCC. Laju aliran air dan minyak tanah diatur dengan menggunakan gate valve yang terpasang pada masing - masing pipa dan diukur menggunakan rotameter yang terpasang pada saluran air dan turbine digital flowmeter pada saluran minyak. Sebagai pengaman pada sistem aliran digunakan check valve untuk menghindari terjadinya aliran balik (back flow) pada sistem LLCC. Campuran aliran air dan minyak dari mixture tube kemudian menuju pipa inlet LLCC (ID $16 \mathrm{~mm}$ ) secara tangensial. Inlet tangensial ini akan menghasilkan aliran vortex di dalam LLCC. LLCC memiliki dua saluran keluar (outlet), yaitu overflow dan underflow. Laju aliran pada outlet baik pada overflow maupun underflow masing - masing diatur menggunakan gate - valve untuk mengatur split - ratio. Split - ratio didefinisikan sebagai perbandingan antara laju aliran volume pada overflow dengan laju aliran volume pada inlet dan merupakan salah satu parameter operasi dari LLCC. Split - ratio dihitung dengan menggunakan Persamaan 1. 
$S R=\frac{Q_{o}}{Q_{i}} \times 100 \%$

Dengan : $Q_{o}=$ Laju aliran volume di overflow.

$Q_{i}=$ Laju aliran volume diinlet.

Aliran kaya minyak akan keluar melewati overflow dan aliran kaya air akan keluar melalui underflow Kedua aliran ini mengalir menuju tangki separator untuk dipisahkan lebih lanjut dengan metode gravitational - based separator. Air dan minyak yang sudah terpisah, masing masing dipompa menggunakan pompa sirkulasi sehingga minyak murni yang terpisah dapat dikembalikan ke tangki penampungan minyak, sedangkan untuk air dipompa ke tempat penampungan lain. Pada overflow, underflow dan inlet terdapat saluran yang digunakan untuk mengambil sampel. Sampel ini kemudian diukur untuk mengetahui kinerja dari LLCC.

Dimensi dan foto LLCC yang digunakan dalam penelitian ini ditunjukkan pada Error! Reference source not found.. LLCC terbuat dari pipa akrilik (transparan) untuk memungkinkan pengamatan proses separasi di dalam LLCC secara visual. LLCC mempunyai panjang penampang vertikal $1300 \mathrm{~mm}(\mathrm{H})$ dengan diameter dalam ID 50 $\mathrm{mm}$ (D). Inlet dengan diameter dalam ID 16 $\mathrm{mm}$ terpasang horizontal pada LLCC secara tangensial terhadap pipa vertikal $300 \mathrm{~mm}(\mathrm{~h})$ di bawah puncak LLCC. Aliran underflow menggunakan pipa dengan diameter dalam ID $18 \mathrm{~mm}$.

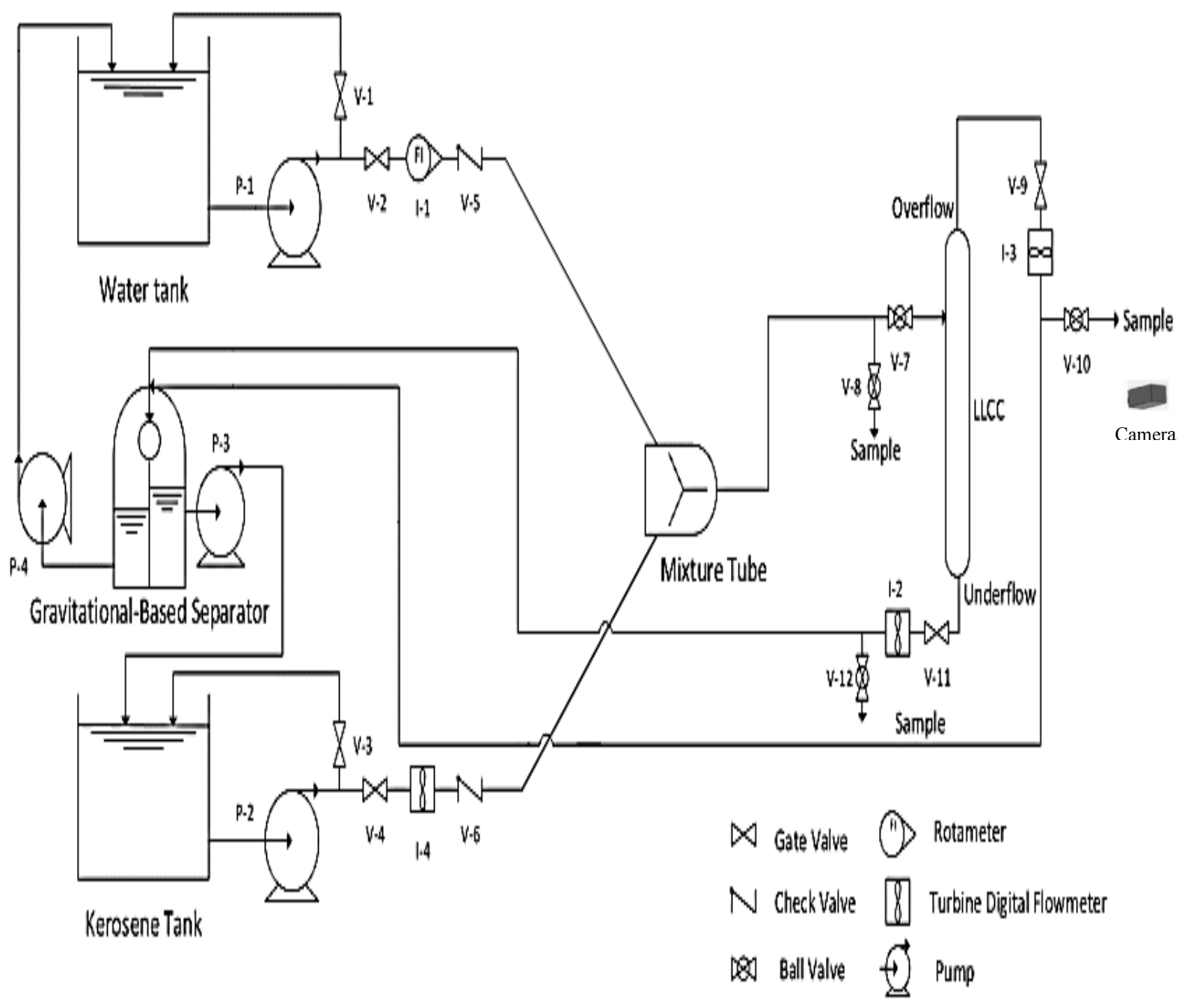

Gambar 1. Skema Dari Fasilitas Eksperimental LLCC. 
Tabel 1. Parameter Desain Non-Dimensi

\begin{tabular}{|c|c|c|c|}
\hline $\begin{array}{c}\text { Parameter Non - } \\
\text { Dimensi }\end{array}$ & Penelitian ini & $\begin{array}{c}\text { Oropeza Vazquez, dkk. } \\
(\mathbf{2 0 0 4 )}\end{array}$ & $\begin{array}{l}\text { H.-f. Liu, dkk. } \\
\text { (2012) }\end{array}$ \\
\hline $\mathrm{d} / \mathrm{D}$ & $\begin{array}{l}0,32 \text { (tanpa } \\
\text { nosel) }\end{array}$ & $\begin{array}{l}0,53 \text { dengan nosel pada } \\
\text { inlet ( } 25 \% \text { dari luas } \\
\text { penampang pipa inlet) }\end{array}$ & $\begin{array}{l}\text { 0,44 dengan nosel } \\
\text { pada inlet ( } 20 \% \text { dari } \\
\text { luas penampang } \\
\text { pipa inlet) }\end{array}$ \\
\hline $\mathrm{h} / \mathrm{H}$ & 0,23 & 0,47 & 0,11 \\
\hline $\mathrm{D}$ & $50 \mathrm{~mm}$ & $50,8 \mathrm{~mm}$ (2 inch) & $50 \mathrm{~mm}$ \\
\hline $\mathrm{H}$ & $1300 \mathrm{~mm}$ & $2413 \mathrm{~mm}$ (95 inch) & $900 \mathrm{~mm}$ \\
\hline
\end{tabular}

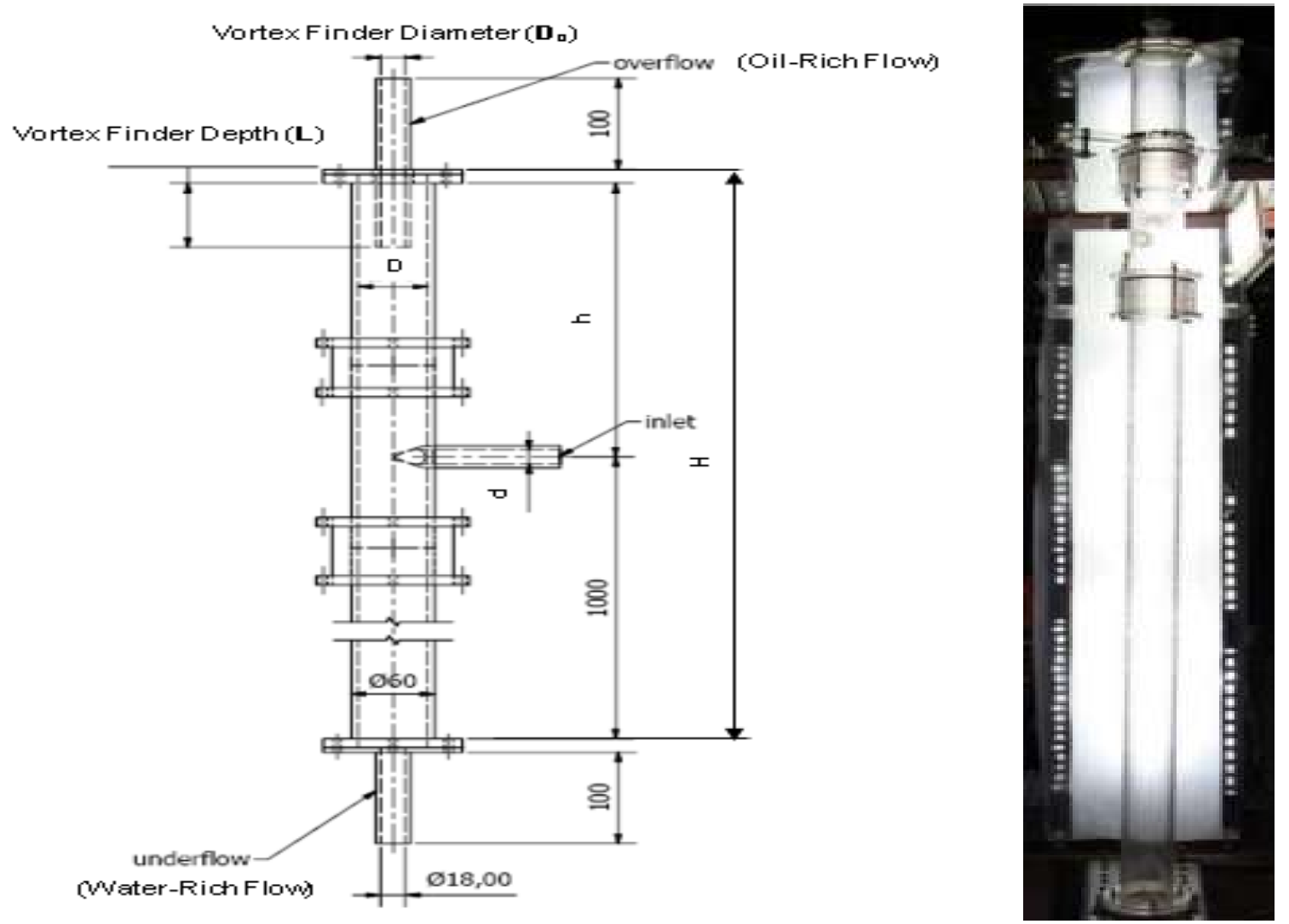

Gambar 2. Dimensi dan Foto LLCC.

Tabel 1 menunjukkan perbandingan desain LLCC dengan studi lain menggunakan parameter non-dimensi. Dapat dilihat bahwa desain LLCC yang digunakan dalam penelitian ini berbeda dengan yang sudah pernah diteliti sehingga data eksperimen yang didapatkan dapat digunakan sebagai database terpadu LLCC.
Dalam penelitian ini, efek parameter lain seperti viskositas minyak (jenis minyak yang digunakan), gesekan pipa, suhu, diabaikan (batasan masalah). Penelitian ini memfokuskan pada parameter operasi dan desain. Kecepatan aliran masuk divariasikan $0,7 \mathrm{~m} / \mathrm{s}, 0,9 \mathrm{~m} / \mathrm{s}$ dan $1,1 \mathrm{~m} / \mathrm{s}$. Nilai split-ratio yang digunakan adalah 5\%, 15\%, 30\%, 45\%, $60 \%, 75 \%$ dan $90 \%$. 
Parameter operasidi atas diujikan pada tiga variasi diameter vortex finder (parameter desain) yaitu $18 \mathrm{~mm}, 22 \mathrm{~mm}$, dan $27 \mathrm{~mm}$ tanpa kedalaman $(\mathrm{L}=0 \mathrm{~mm})$.

Pengujian di atas dilakukan dengan fraksi volume inlet konstan pada nilai $25 \%$.Untuk pengamatan dan pengambilan data visual (foto), kamera dengan spesifikasi frame rate 1000 - $3000 \mathrm{fps}$, dan resolusi maksimum 1280 x 800 piksel ditempatkan di depan LLCC. Lampu LED dengan daya 50 Watt digunakan sebagai sumber cahaya.

\section{HASIL DAN PEMBAHASAN}

Bab ini menjelaskan dan mengalisis hasil eksperimen yang menunjukkan performa dari LLCC dengan parameterparameter telah disebutkan.

Dalam penelitian ini LLCC digunakan sebagai alat untuk menghasilkan air bersih. Secara umum hydrocylone atau LLCC digunakan sebagai langkah akhir untuk membersihkan kandungan minyak yang masih terkandung dalam air hasil pemisahan menggunakan separator utama / conventional separator sampai level minimum (mendekati 100\% konsentrasi air bersih) sehingga air tersebut aman / legal untuk dibuang ke laut (Stones, 2007). Namun, hasil pemisahan dari LLCC tidak hanya menghasilkan air bersih tetapi juga menghasilkan minyak dengan kandungan cukup banyak yang keluar melalui overflow. Berbeda dengan hasil air bersih yang mampu mencapai konsentrasi mendekati 100\%, minyak yang dihasilkan LLCC dari proses pemisahan masih mengandung jumlah air yang cukup banyak.

Jumlah air bersih yang dihasilkan oleh LLCC sering disebut sebagai watercut yang keluar melalui underflow. Performa dari LLCC ditunjukkan oleh kemampuan menghasilkan watercut dengan parameter operasi yang berubah - ubah. Hasil eksperimen terhadap presentase watercut ditunjukkan oleh Gambar 3.

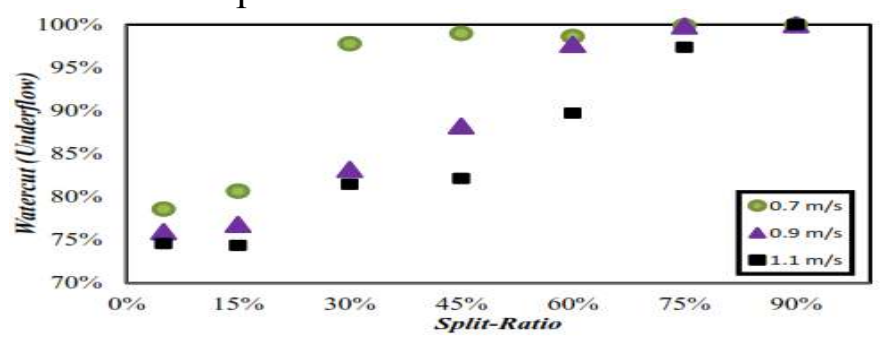

(a)

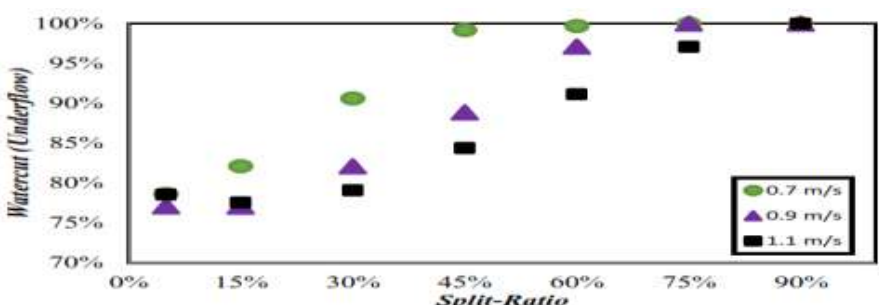

(b)

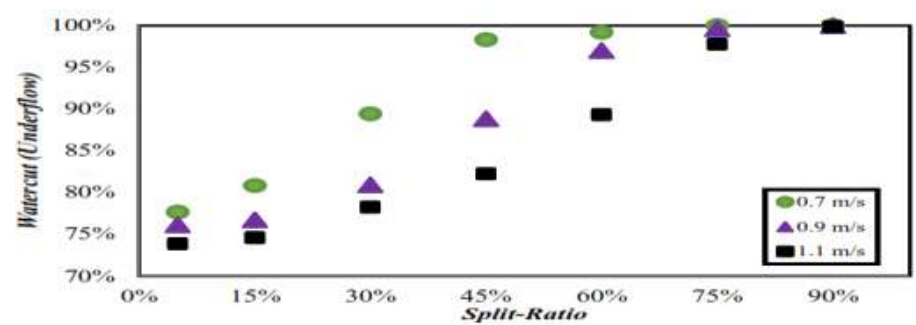

(c)

Gambar 3. Pengaruh Split-ratio dan Kecepatan Aliran Masuk terhadap Watercut; (a) $D_{o}=18 \mathrm{~mm}$; (b) $D_{o}=22 \mathrm{~mm}$; (c) $D_{o}=27 \mathrm{~mm}$. 
Grafik terebut menunjukkan bahwa semakin besar split-ratio maka nilai watercut pada underflow akan semakin besar untuk kemudian mencapai nilai maksimum pada masing - masing variasi diameter vortex finder. Hal ini disebabkan karena pada saat nilai split - ratio rendah maka laju aliran yang pada overflow akan rendah sehingga minyak akan cenderung terdorong ke arah underflow dan megurangi nilai watercut. Sedangkan pada saat nilai split - ratio tinggi, maka laju aliran pada overflow akan tinggi yang mengakibatkan minyak cenderung terdorong ke arah overflow sehingga nilai watercut akan meningkat.

Nilai split - ratio dimana minyak mulai menyentuh bagian bawah LLCC atau underflow (oil drag) disebut sebagai Optimum Split-Ratio (OSR). Saat nilat split ratio berada di bawah OSR maka nilai watercut mulai turun dari nilai maksimumnya. Untuk mencapai performa maksimum maka LLCC harus dioperasikan dengan split - ratio diatas nilai OSR. Secara umum, nilai watercut paling baik didapat saat nilai split - ratio $60 \%$ ke atas, dimana LLCC dapat menghasilkan watercut mencapai hampir $100 \%$.
Gambar 4 menunjukkan foto proses pemisahan di dalam LLCC untuk diameter vortex finder $22 \mathrm{~mm}$ dan kecepatan aliran masuk $0,9 \mathrm{~m} / \mathrm{s}$. Dalam foto tersebut terlihat bahwa saat dioperasikan pada nilai OSR minyak mulai bergerak ke arah underflow. Data visualisasi untuk variasi kecepatan aliran masuk dan diameter vortex finder yang lain menunjukkan tren maupun karakteristik yang sama dengan Gambar 4.

Sedangkan perubahan parameter operasi kecepatan aliran masuk mengakibatkan perubahan nilai OSR. Saat kecepatan rendah $\left(V_{m}=0,7 \mathrm{~m} / \mathrm{s}\right)$ watercut akan mencapai nilai maksimum saat dioperasikan dengan splitratio diatas $45 \%$ (OSR $=45 \%)$ untuk masing - masing diameter vortex finder. Ketika kecepatan aliran masuk naik menjadi $V_{m}=0,9 \mathrm{~m} / \mathrm{s}$ maka nilai OSR akan naik menjadi 75\%. Untuk kecepatan aliran masuk paling tinggi yaitu $\mathrm{Vm}=1,1 \mathrm{~m} / \mathrm{s}$ nilai OSR yang didapatkan juga $75 \%$. Dengan bertambahnya kecepatan aliran masuk, maka gaya sentrifugal yang terjadi akan semakin besar. Gaya sentrifugal yang terlalu besar justru akan membuat minyak terpecah menjadi droplet-droplet / bulir - bulir kecil. Buoyancy dari bulir - bulir yang terlalu kecil akan sangat rendah sehingga akan terhambur ke arah underflow.

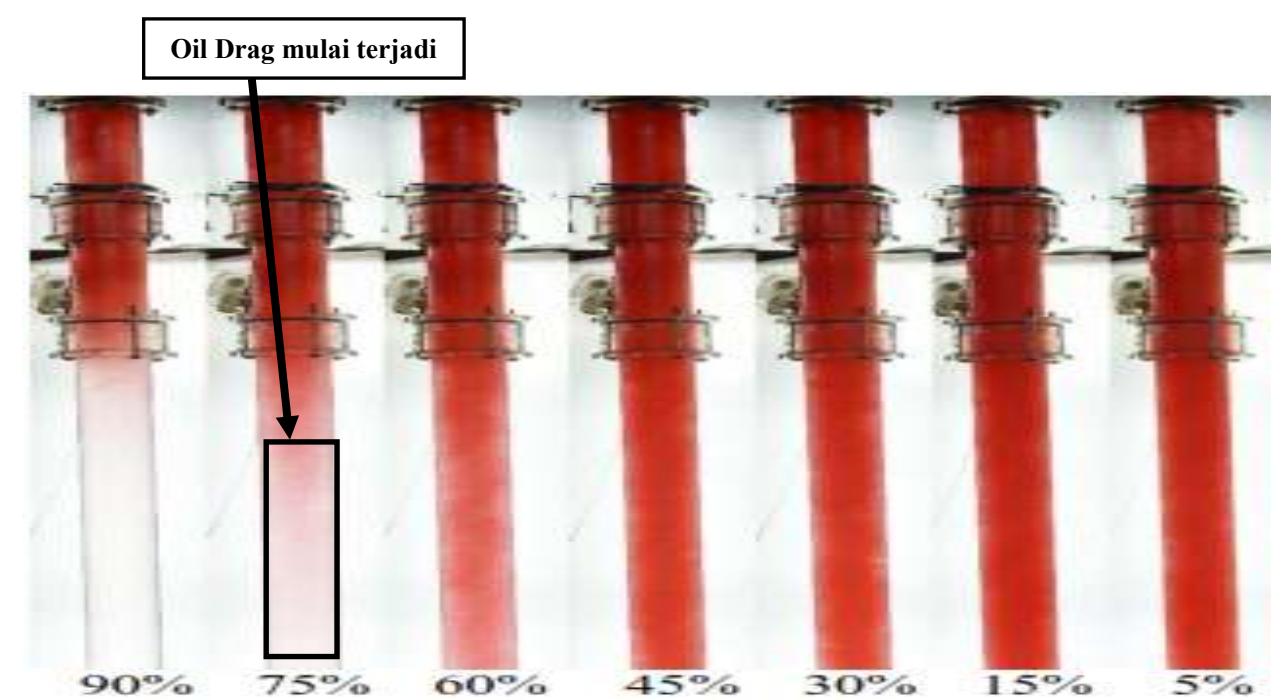

Gambar 4. Data Visual Pengaruh Split-ratio Terhadap Proses Pemisahan di Dalam LLCC.

$(D o=22 \mathrm{~mm}, V m=0.9 \mathrm{~m} / \mathrm{s})$ 
Hal ini mengakibatkan untuk nilai kecepatan aliran masuk yang tinggi dibutuhkan nilai split - ratio yang tinggi pula agar LLCC mencapai performa maksimum. Diameter vortex finder yang membesar mengakibatkan nilai watercut meningkat walaupun tidak signifikan untuk pengoperasian dengan nilai split - ratio dan kecepatan aliran masuk yang sama. Diameter vortex finder yang besar akan mempermudah aliran mengalir melalui overflow sehingga kandungan minyak akan lebih mudah mengalir ke overflow. Hal ini akan mengakibatkan nilai watercut meningkat.

Gambar 5 menunjukkan perbandingan hasil penelitian dengan hasil penelitian yang dilakukan oleh (Dharma, 2014) dan (Hilmy, 2016) pada tiga variasi diameter vortex finder yang sama namun dengan kecepatan aliran masuk yang berbeda. (Dharma, 2014) melakukan eksperimen dengan kecepatan aliran masuk sebesar $1,3 \mathrm{~m} / \mathrm{s}$ dan $1,6 \mathrm{~m} / \mathrm{s}$ dengan nilai split - ratio divariasikan pada rentang $25 \%$ sampai $85 \%$. Sedangkan (Hilmy, 2016) melakukan eksperimen dengan kecepatan aliran masuk sebesar 0.6 $\mathrm{m} / \mathrm{s}, 0.8 \mathrm{~m} / \mathrm{s}$ dan $1.0 \mathrm{~m} / \mathrm{s}$. dengan nilai split ratio $5 \%, 15 \%, 30 \%, 45 \%, 60 \%, 75 \%$, dan $90 \%$.

Pada penelitian ini, nilai watercut yang didapatkan mencapai hampir 100\%. Nilai maksimum watercut ini sama dengan studi yang dilakukan oleh (Hilmy, 2016). Berbeda dengan eksperimen yang dilakukan oleh (Dharma, 2014) nilai maksimum watercut yang dicapai hanya 93\%. Hal ini diakibatkan oleh kecepatan aliran masuk yang terlalu tinggi. Pengoperasian LLCC dengan kecepatan yang terlalu tinggi justru akan menghamburkan campuran air dan minyak sehingga fungsi dari LLCC akan terbalik menjadi alat pengaduk. Gambar 5 juga menunjukkan bahwa semakin tinggi kecepatan aliran masuk maka nilai OSR juga semakin besar.

Agar LLCC memperoleh performa maksimum sebagai penghasil air bersih, maka LLCC harus dioperasikan dengan nilai split-ratio sesuai dengan OSR pada masing masing kecepatan aliran masuk. Dengan mengoperasikan LLCC pada nilai OSR, maka laju aliran air bersih yang didapatkan juga akan mencapai nilai maksimumnya.

\section{KESIMPULAN}

Berdasarkan data hasil eksperimen dan pembahasan di atas maka dapat diambil kesimpulan sebagai berikut :

a. Semakin tinggi nilai split - ratio, maka nilai watercut akan naik untuk kemudian mencapai nilai maksimum. LLCC berhasil mendapatkan nilai watercut mencapai hampir $100 \%$ dengan nilai split - ratio diatas $60 \%$.

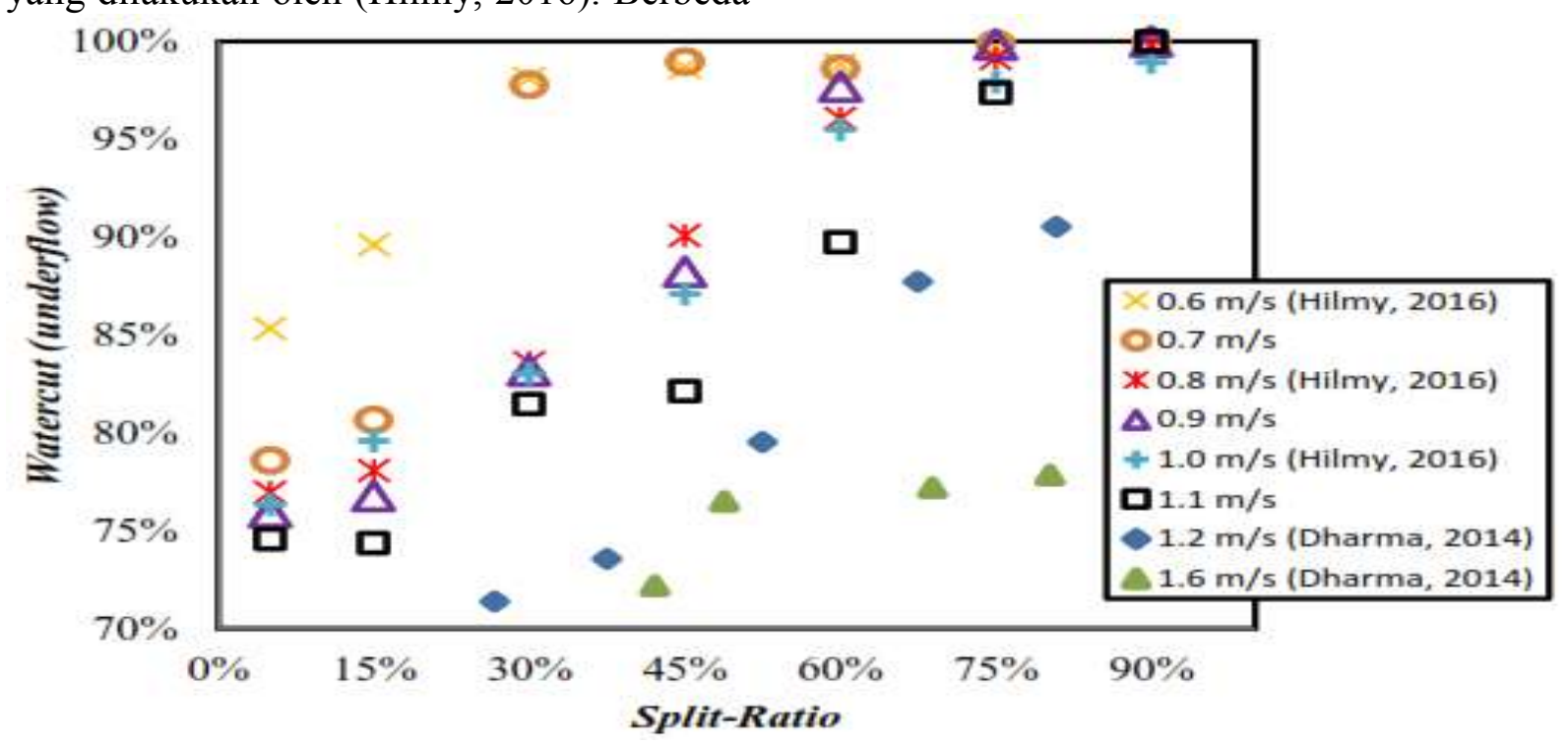

Gambar 5. Perbandingan Hasil Eksperimen Dengan Studi Lainnya. 
b. LLCC harus dioperasikan pada nilai OSR agar mencapai performa maksimum. (Nilai watercut mencapai hampir $100 \%$ dan laju aliran watercut yang keluar melalui underflow mencapai nilai maksimum).

c. Kecepatan aliran masuk yang semakin tinggi mengakibatkan nilai OSR semakin besar.

d. Perubahan diameter vortex finder tidak menghasilkan perubahan performa LLCC yang signifikan.

\section{Ucapan Terimakasih}

Ucapan terimakasih disampaikan kepada Departemen Teknik Mesin dan Industri yang telah membiayai penelitian ini dalam skema Hibah Penelitian Dosen dan Kementerian Riset, Teknologi, dan Pendidikan Tinggi Republik Indonesia dalam skema Penelitian Fundamental pada tahun anggaran 2016 2017.

\section{DAFTAR PUSTAKA}

Berdnasky, S., \& Listewnik, J. Hydrocyclones for simultaneous removal of oil and solid particle from ships oily waters. Filtration and Separation, 92-97., 1988.

Dharma, I. A. Studi Eksperimental Pemisahan Air Dan Minyak Tanah (Kerosene) Dalam Liquid-Liquid Cylindrical Cyclone (LLCC) (Tugas Akhir). Universitas Gadjah Mada, Yogyakarta., 2014.

Dharma, I. A., Arffan, F., Prambudi, A. R., Widyaparaga, A., Pranoto, I., \& Khasani. Development of liquidliquid cylindrical cyclone (LLCC) separator for oil-water separation (hlm. 040013). Dipresentasikan pada Proceedings of the 3rd AUN/SEED-NET Regional Conference on Energy Engineering and the 7th International Conference on Thermofluids (Rcene/thermofluid 2015), AIP Conference Proceedings. https://doi.org/10.1063/1.494930., 2016.
Eryanto, E., \& Achmadi, T. Analisis Penanganan Limbah Minyak di Kawasan Pelabuhan: Tinjauan dari Segi Transportasi Laut. Jurnal Teknik ITS, 1., 2012.

Hilmy, S. I. Studi Eksperimental Pengaruh Oil Volume Fraction Inlet Dan Kecepatan Aliran Masuk Terhadap Unjuk Kerja Liquid-Liquid Cylindrical Cyclone (LLCC) (Tugas Akhir). Universitas Gadjah Mada, Yogyakarta., 2016.

Listewnik, J. Some factors influencing the performance of de-oiling hydrocyclones for marine applications. (hlm. 191-204). Dipresentasikan pada 2nd International Conference on Hydrocyclones, England: BHRA Fluid Engineering., 1984.

Liu, H., Xu, J., Wu, Y., \& Zheng, Z. Numerical study on oil and water two-phase flow in a cylindrical cyclone. Journal of Hydrodynamics, Ser. B, 22(5), 832-837. https://doi.org/10.1016/S10016058(10)60038-8., 2010.

Liu, H., Xu, J., Zhang, J., Sun, H., Zhang, J., $\& \mathrm{Wu}, \mathrm{Y}$. Oil/water separation in a liquid-liquid cylindrical cyclone. Journal of Hydrodynamics, Ser. B, 24(1), 116-123. https://doi.org/10.1016/S1001-6058 (11) 60225-4., 2012.

Oropeza-Vazquez, C., Afanador, E., Gomez, L., Wang, S., Mohan, R., Shoham, O., \& Kouba, G. Oil-Water Separation in a Novel Liquid-Liquid Cylindrical Cyclone (LLCCC) Compact Separator-Experiments and Modeling. Journal of Fluids Engineering, 126(4), 553., https://doi.org/10.1115/1.1777233., 2004.

Stones, A. C. Oil/Water Separation in A Novel Cyclone (Doctoral Thesis). Cranfield University, Bedford., 2007. 